Discussion Paper No. 12-013

\title{
Small Firm Innovation Performance and Employee Involvement
}

Petra Andries and Dirk Czarnitzki

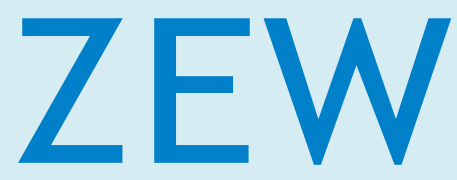

Zentrum für Europäische Wirtschaftsforschung $\mathrm{GmbH}$

Centre for European Economic Research 
Discussion Paper No. 12-013

\title{
Small Firm Innovation Performance and Employee Involvement
}

\author{
Petra Andries and Dirk Czarnitzki
}

Download this ZEW Discussion Paper from our ftp server:

http://ftp.zew.de/pub/zew-docs/dp/dp12013.pdf

Die Discussion Papers dienen einer möglichst schnellen Verbreitung von neueren Forschungsarbeiten des ZEW. Die Beiträge liegen in alleiniger Verantwortung der Autoren und stellen nicht notwendigerweise die Meinung des ZEW dar.

Discussion Papers are intended to make results of ZEW research promptly available to other economists in order to encourage discussion and suggestions for revisions. The authors are solely responsible for the contents which do not necessarily represent the opinion of the ZEW. 


\section{Non-technical Summary}

It is known that small firms rely mainly on the CEO's individual knowledge for developing innovations (Burton, 2001; Cook, 1999). Recent work suggests that this approach underutilizes other employees' knowledge (Klaas et al., 2010). There is currently limited empirical evidence to support this. While the 'upper echelon' literature finds mixed evidence regarding the link between CEOs' and top managers' human capital and small firms' innovative performance, the role of non-managerial employees for innovation performance has only been studied in large firms.

This paper therefore analyzes to which extent using CEOs', managers' and non-managerial employees ideas affects small firms' innovation performance. It relies on a large-scale survey dataset of 305 small manufacturing and service firms. Firstly, we confirm earlier findings that few small firms involve non-managerial employees in the innovation process. Secondly, we show that using ideas of managers, but also of non-managerial employees positively affects the firm's innovative performance. Thirdly, we find that individuals' contributions depend on their functional area of expertise as well as on whether process or product innovation performance is desired.

Our findings suggest that the historical focus on the entrepreneur/CEO which was broadened more recently to the study of entrepreneurial teams does not yet fully capture small firms' innovative potential. Small firms' CEOs should involve employees in the innovation process, instead of relying solely on their own actions and ideas. However, functional differences as well as differences between product and process innovation need to be taken into account when doing so. 


\section{Das Wichtigste in Kürze (Summary in German)}

Innovationen in kleinen Unternehmen basieren häufig ausschließlich auf den Kenntnissen des Geschäftsführers (Burton, 2001; Cook, 1999). Jüngste Forschungsarbeiten weisen darauf hin, dass dieser Ansatz das Wissen anderer Mitarbeiter nicht hinreichend verwertet (Klaas et al., 2010). Jedoch bestehen bisher kaum empirische Studien, die diese Sichtweise belegen. Zwar findet die sogenannte 'upper echelon' Literatur Hinweise auf Zusammenhänge zwischen dem Humankapital von Top-Managern und der Innovationsleistung kleiner Unternehmen. Jedoch wurde die Rolle von Mitarbeitern ohne Leitungsfunktion im Innovationsprozess kleiner Unternehmen noch nicht untersucht.

Diese Studie untersucht daher empirisch inwieweit die Nutzung von Ideen von Geschäftsführern, anderen Mitarbeiten mit Leitungsfunktionen sowie Mitarbeitern ohne Leitungsfunktion die Innovationsleistung kleiner Unternehmen beeinflussen. Die empirische Analyse beruht auf 305 Beobachtungen kleiner Firmen des Verarbeitenden Gewerbes sowie den unternehmensnahen Dienstleistungen. Die Resultate zeigen, dass (i) tatsächlich nur wenige Firmen Mitarbeiter ohne Leitungsfunktion in den Innovationsprozess mit einbeziehen, und (ii) dass sowohl die Ideennutzung von Mitarbeitern mit Leitungsfunktion sowie auch von Mitarbeitern ohne Leitungsfunktion positiv zur Innovationsleistung beitragen. Ferner findet sich Heterogenität in den Effekten hinsichtlich Prozess- versus Produktinnovation sowie in der Herkunft der Vorschläge für Innovationen. 


\title{
Small firm innovation performance and employee involvement *
}

- revised version is forthcoming in Small Business Economics -

\author{
Petra Andries a,b,c and Dirk Czarnitzki a,b,d \\ a) Dept. of Managerial Economics, Strategy and Innovation, K.U.Leuven, Belgium \\ b) Centre for R\&D Monitoring (ECOOM), K.U.Leuven, Belgium \\ c) Incentim, K.U.Leuven, Belgium \\ d) Centre for European Economic Research (ZEW), Mannheim, Germany
}

This version: December 2011

\begin{abstract}
It is known that small firms rely mainly on the CEO's individual knowledge for developing innovations. Recent work suggests that this approach is inefficient since it underutilizes other employees' knowledge. We study to which extent using CEOs, managers and non-managerial employees' ideas enhances small firms' innovation performance. A Heckman selection model on 305 small firms shows that not only CEO's and managers', but also non-managerial employees' ideas contribute to innovation performance. However, contributions depend heavily on the individuals' area of expertise and on whether product or process innovation is desired. Our findings enrich the current view on the entrepreneurial team, but also warn against the implementation of one-size-fits-all employee involvement programs in small firms.
\end{abstract}

Keywords: $\quad$ Employee involvement, upper echelon, non-managerial employees, innovation performance, small firms

JEL-classification: M12, O31, O32

\section{Contact details:}

Petra Andries, Centre for R\&D Monitoring (ECOOM), Waaistraat 6, 3000 Leuven; Phone: +32 16325 761, Fax: +32 16325 799, E-mail: petra.andries@econ.kuleuven.be

Dirk Czarnitzki, K.U.Leuven, Dept. of Managerial Economics, Strategy and Innovation, Naamsestraat 69, 3000 Leuven, Belgium;

Phone: +32 16326 906, Fax: +32 16326 732, E-mail: dirk.czarnitzki@econ.kuleuven.be

\footnotetext{
${ }^{*}$ Acknowledgements: Czarnitzki gratefully acknowledges financial support from the Flemish Science Foundation (FWO, grant G.0282.10). We also thank the ZEW Mannheim for providing the data access and Alfred Spielkamp for helpful comments.
} 


\section{Introduction}

Firms' pursuit of competitive advantage vis-à-vis competitors is a central topic in strategic management (Teece et al., 1997). Technological innovation is frequently cited as a base for such an advantage and the characteristics or factors that affect firm performance in innovation (or innovativeness) are therefore an important investigation area. It is widely accepted that an organization's capability to innovate is closely tied to its intellectual capital, i.e. to its ability to utilize its individual knowledge resources. Several studies emphasize how new products and processes embody knowledge (e.g. Stewart, 1997), describe innovation as a knowledge management process (e.g. Madhavan and Grover, 1998) and characterize innovative companies as knowledge creating (e.g. Nonaka and Takeuchi, 1995). There is a clear link between individual knowledge and innovation.

Small firms rely mainly on their CEO's knowledge to innovate (Burton, 2001). Small firms' leaders regard their own activities as sufficient and seldom involve employees in unique and valuable activities such as developing innovations (Klaas et al., 2010) and human capital programs are not commonly used in small businesses (Cook, 1999). Recently, scholars have questioned whether small firms' dependence on the CEO's individual knowledge is efficient or whether it actually underutilizes other employees' talents and knowledge (Klaas et al., 2010). There is currently limited empirical evidence to convincingly answer this question. On the one hand, a number of articles adhering to the 'upper echelon perspective' study the link between CEOs' and top managers' human capital and small firms' innovative performance. The results are mixed. While some studies (e.g. Chaganti et al., 2008) find a positive relationship, others observe no relationship (e.g. Lynskey, 2004). A study by De Winne and Sels (2010) finds that owners' and managers' human capital has no direct effect on new ventures' innovative output, but only an indirect effect in the sense that highly educated CEOs and managers tend to hire 
more highly educated employees and tend to use more human resource practices (see also Bergmann Lichtenstein and Brush, 2001; Borch et al., 1999; Schuler and Jackson, 1987); two factors which in turn increase the venture's innovation intensity. On the other hand, there is limited understanding of how non-managerial employees contribute to firms' new product or process development (Wales et al., 2011; Slevin and Terjesen, 2011). Most articles that do study the effect of employee involvement on innovation performance - in line with the strategic view of human resource management - look at large established firms, whereas studies on small firms are almost non-existing (for an exception see De Winne and Sels, 2010).

This paper therefore analyzes to which extent using CEOs', managers' and non-managerial employees ideas affects small firms' innovation performance. The analysis relies on a dataset of 305 small manufacturing and service firms, collected through a large-scale survey. The main results can be summarized as follows. Firstly, descriptive statistics confirm earlier findings that few small firms involve non-managerial employees in the innovation process. Secondly, the regression results show that using ideas of managers, but also of non-managerial employees has a positive impact on the firm's innovative performance. This suggests that the historical focus on the entrepreneur/CEO which was broadened more recently to the study of entrepreneurial teams does not yet fully capture small firms' innovative potential. Small firms' CEOs should involve employees in the innovation process, instead of relying solely on their own actions and ideas. Thirdly, we find that individuals' contributions depend on their functional area of expertise as well as on the desired innovation; more precisely, on whether process or product innovation performance is desired. This implies that both functional differences as well as differences between product and process innovation need to be taken into account when a firm intends to engage employees in its innovation process.

The article is structured as follows. The next section introduces the theoretical background and presents hypotheses. The subsequent section describes the data and model used to test 
the hypotheses. The paper then outlines the results and concludes with a general discussion and suggestions for further research.

\section{Theoretical Framework}

\subsection{Innovation, individual knowledge and the resource-based view of the firm}

According to contemporary strategic management theories, firms can generate rents by creating and sustaining sources of competitive advantage (Liebeskind, 1996; Bowman, 1974; Barney, 1986). In the resource based view of the firm, resources and capabilities are regarded as the principal sources of such sustainable competitive advantage (Grant, 1996a; Argote et al., 2003; Eisenhardt and Martin, 2000; Helfat and Raubitschek, 2000; Henderson and Cockburn, 1994; lansiti and Clark, 1994; Klepper and Simons, 2000), on the condition that these resources and capabilities are valuable, unique and not easily transferable or replicable (Barney, 1991; Grant, 1991; Amit and Schoemaker, 1993). The firm is perceived as a unique bundle of idiosyncratic resources and capabilities where management needs to maximize value through the deployment of existing resources and capabilities as well as the development of resources and capabilities for the future (Grant, 1996a).

The firm's innovative capacity is put forward as one of the most important capabilities for developing a sustainable competitive advantage. Innovation is intrinsically about identifying and using opportunities to create new products, services, or work practices. The rate at which firms develop new products, services and processes impacts firm performance and long-term survival (Banbury and Mitchell, 1995; Damanpour, 1991). By introducing new products, services and processes, organizations can become more efficient, can adapt to meet market demands (Brown and Eisenhardt, 1995) and can even establish new markets (Burgelman, 1991). 
In line with the resource based view of the firm, it is widely accepted that the ability to innovate depends on the firm's underlying resources and capabilities (Kusunoki et al., 1998). A key principle in the literature on new product development is that the new product introduction rate is a function of a firm's ability to manage, maintain and create knowledge (Nonaka, 1991; Nonaka and Takeuchi, 1995; Cohen and Levinthal, 1990; Drazin and Rao, 2002, Kogut and Zander, 1992; Henderson and Clark, 1990). A critical portion of this knowledge required for innovation resides with individuals (Subramaniam and Youndt, 2005; Hansen, 1999; Szulanski, 1996). Individuals are the primary agents of knowledge creation and in the case of tacit knowledge, the principal repositories of knowledge (Grant, 1997). In addition, individual knowledge and skills (like other intangible resources such as brand equity) are more likely to product a competitive advantage because they are often rare and socially complex, thereby making them difficult to imitate (Hitt et al., 2001). As a result, human capital is regarded as a critical resource in developing innovations and a sustainable competitive advantage (Hitt et al., 2001; Barney, 1991; 1995; Lado and Wilson, 1994; Barney and Wright, 1998; Huselid, 1995; Wright and McMahan, 1992; Wiig, 1997)!. Although many other factors play a role in the idea generation process (Amabile, 1983; Mumford and Gustafson, 1988; Ward, 2004), individual knowledge is important for generating ideas, which in turn can become relevant when used in the innovation process (Bledow et al., 2009). We therefore hypothesize that:

H1: Using individuals' ideas in the innovation process has a positive effect on small firms' innovation performance.

\footnotetext{
" While a critical portion of knowledge and skills resided with individuals, it must be noted that innovation is a collective achievement (Kogut and Zander, 1992; Cohen and Levinthal, 1990). Organizations accumulate and store individual knowledge for collective use (Garud and Nayyar, 1994) and establish structures and procedures to streamline individual ideas into streams of innovative outcomes (Cooper, 2001; Allen, 1977; Kogut and Zander, 1992; 1993, 1996; Nonaka and Taekuchi, 1995; Spender, 1996; Conner and Prahalad, 1996; Zander and Kogut, 1995; Nahapiet and Ghoshal 1998).
} 


\subsection{The upper echelon perspective}

The upper echelon perspective emphasizes the role of top management's skills and knowledge for firms' innovative performance. This literature stream argues that organizational outcomes both strategies and effectiveness - can be viewed as reflections of the values and cognitive bases of powerful actors in the organization (Hambrick and Mason, 1984). At the basis of the upper echelon perspective is the assumption that strategic choices are taken by CEOs and top managers. The CEO is often the central strategic decision maker and can compose the organization's top strategy-making group (Zahra and Pearce, 1989). CEOs and top managers are responsible for developing and implementing the firm's strategy. In this view, CEOs and managers represent a unique organizational resource (Daily et al., 2000; Hitt et al., 2001; Baird and Meshoulam, 1988), which contributes to the firm's competitive advantage.

As prior research suggests that CEOs' and top managers' values and cognitive bases are difficult to measure, most studies instead use human capital - derived from education and past experience - as a proxy (Chaganti and Sambharya, 1987; Barker and Mueller, 2002; Miller and Toulouse, 1986; Patzelt et al., 2009; Davidsson and Honig, 2003). This is based on the argument that formal education and previous experience determine one's skills and knowledge base (Lynskey, 2004; Boeker, 1997). CEOs' and top managers' human capital is thought to affect the firm's innovative performance in both a direct and an indirect way. Firstly, highly educated and more experienced owners/managers are expected to be more successful in opportunity recognition (Hambrick and Mason, 1984; Shane, 2000; Shane and Venkatraman, 2000; Ucbasaran et al., 2009), thereby directly contributing ideas and insights to the firm's innovation performance. Secondly, owners/managers' knowledge is helpful for acquiring resources (Brush et al., 2001), including human resource selection and management (Bergmann Lichtenstein and Brush, 2001; Borch et al., 1999; Schuler and Jackson, 1987), which in turn have an impact on the accumulation of knowledge and skills. Moreover, 
managers who display confidence and satisfaction about entrepreneurial projects enhance employees' willingness to act entrepreneurially (Brundin et al., 2008). CEOs and top managers are hence believed to have also an indirect effect on firm's innovation performance.

In line with the upper echelon view, a vast number of small business studies investigate the effect of the founder's human capital on venture success in general (e.g. Davidsson and Honig, 2003; Zarutskie, 2010). Although these studies differ in their measurement of human capital and in the measurement of venture success (including size, growth, profitability, etc.), a metaanalysis by Unger et al. (2011) shows that the founder's human capital is indeed a predictor of venture success, especially in terms of size (as compared to growth or profitability). When it comes specifically to small firms' innovative performance, empirical evidence on the effect of the founder's human capital is however mixed. Whereas Chaganti et al. (2008) discover a relationship between the founding team members' background and new ventures' propensity to seek and pursue entrepreneurial opportunities, Lynskey (2004) on the contrary, does not find any link between the CEO's human capital and new product development in new ventures. Similarly, Davidsson and Honig (2003) do not find an effect of the entrepreneur's human capital on first product sales or profitability. A study by De Winne and Sels (2010) suggests that new ventures' owners and managers do not contribute directly to the firms' innovative output by generating ideas or recognizing opportunities, but instead only contribute indirectly by hiring more highly educated employees and by using more human resource practices. Although empirical findings are inconclusive, we follow the upper echelon perspective in hypothesizing that:

H2: Using the CEO's ideas in the innovation process has a positive effect on small firms' innovation performance.

H3: Using managers' ideas in the innovation process has a positive effect on small firms' innovation performance. 


\subsection{Employee involvement and the strategic view of human resource management}

At the same time however, many researchers acknowledge that a firm's strategy is not always driven by its top managers (Mintzberg and Waters, 1985; Burgelman, 1983; Stopford and Baden-Fuller, 1994). Parallel to the upper echelon perspective, a literature stream has developed which emphasizes the crucial role of non-managerial employees' skills and knowledge for innovation and firm performance. Key employees' natural abilities, intelligence and skills acquired from formal education and job experience are regarded to constitute an important part of an organization's human capital (Grant, 1997). Orlikowksi (2002) suggests that the competence to do product development is grounded in organizational members' everyday, routine practices (see also Hutchins, 1991; Suchman, 1987). Non-managerial employees are expected to recognize opportunities (Mintzberg and Waters, 1985) and to drive organizational performance (Bartlett and Ghoshal, 1993). Empirical work on large established firms (e.g. Smith et al. 2005) indeed confirms that non-managerial employees' human capital has a positive impact on the firm's knowledge creating capability.

In line with these findings, researchers have studied how human resource practices can contribute to organizational performance such as firm productivity, innovativeness or growth (Wright et al., 2001; Fey et al., 2000). As explained by Collins and Smith (2006), this strategic view of human resource management emphasizes that companies can implement a variety of HR practices that motivate employees to contribute to firm performance - including innovation by aligning their interests with those of the firm (Tsui et al., 1997 Ciavarella, 2003; Huselid, 1995).

Characteristic of these so-called "commitment-based" HR practices (see e.g. Lado and Wilson, 1994; Zenger and Hesterly, 1997; Drazin et al., 1999) is that they increase 
decentralization and involvement, in the sense that problem-solving rights are delegated in such a way that they are co-located with relevant knowledge. Involving and empowering frontline employees may allow better for the discovery and utilization of local knowledge in the organization (Ciavarella, 2003), particularly when there are incentives in place that foster such discovery (Argote et al., 2003). Empirical studies of large, established firms indeed confirm that firms' productivity and innovative performance is related to high degrees of decentralization and involvement, which include employees being able to participate in decision-making, responsibilities being delegated, manual employees being involved with formal or informal work teams and/or quality circles and employee proposals being systematically collected (e.g. Kalleberg and Moody, 1994; Michie and Sheehan-Quinn, 2001; Hayton, 2003; Michie and Sheehan, 1999; Datta et al., 2005).

As for small firms however, it is well known that very few of them adopt HR practices (Klaas et al., 2010). Most rely solely on the CEO's knowledge. However, some evidence suggests that non-managerial employees do have the potential to contribute to small firm innovation. Surveys show that some small firms' owners/managers consider employees an important resource (Bergmann Lichtenstein and Brush, 2001) and a prerequisite for product innovation (Roper et al., 1996). Work by Klaas et al. (2010) suggests that especially CEOs with previous exposure to HR practices, understand the value of such practices". We therefore hypothesize that:

H4: Using non-managerial employees' ideas in the innovation process has a positive effect on small firms' innovation performance.

\footnotetext{
II Some studies on SMEs also find a positive relationship between employees' human capital and sophisticated HRM practices on the one hand and firm performance on the other hand (Hayton, 2003; Way, 2002; Maes et al., 2005; Sels et al., 2006; Rauch et al., 2005). However, they all model financial performance or non-financial outcomes other than innovation. In these studies, the effect of employees' human capital on firms' innovative performance is assumed, but not tested.
} 


\section{Data and Method}

\subsection{Sample}

The hypotheses are tested on a sample of 305 manufacturing and service firms located in the Saarland region, Germany. Company data was collected through a large-scale survey. Firms were randomly selected if they were active in (1) manufacturing, (2) construction, (3) IT services, (4) transportation, or (5) other business services. Overall, the questionnaire was designed very similarly to those of the Community Innovation Survey (see e.g. Eurostat, 2004, for a detailed report and OECD/Eurostat, 1997, for guidelines on how to collect innovation data in the business sector). Unlike the Community Innovation Survey, this survey included questions on the use of individuals' ideas in the innovation process. 419 small firms - i.e. firms with less than 50 employees - replied to the survey, implying a response rate of $20 \%$ l․ Leaving out incomplete answers leads to a final set of 305 small firms. Of these 305 small firms, 146 were active in manufacturing, 58 in construction, 23 in IT services, 35 in transportation and 43 in other business services.

\section{$3.2 \quad$ Variables}

\subsubsection{Dependent variables}

Three dependent variables are considered. As we will outline below, the survey structure is such that an affirmative survey response to our main explanatory variables of interest, the use of individuals' ideas in the innovation process, already implies that the firm developed at least some product or process innovation. Therefore, we first estimate whether a firm innovated at all. The dummy Inno takes the value 1 if the firm indicates that it undertook any kind of innovation activity (product or process) in the last three years and is zero otherwise. This is determined by general firm characteristics, as we describe below.

\footnotetext{
III This response rate is highly comparable with general response rates for surveys of German firms. For example, the Third Community Innovation Survey had a $21 \%$ response rate in Germany (Eurostat, 2004).
} 
Conditional on being innovative at all, we consider two dependent variables representing innovation performance. These depend on idea management among other determinants. Our first performance indicator describes product innovation performance. We follow the work by a.o. Mohnen and Mairesse (2002), Laursen and Salter (2006) and Faems et al. (2005), who measure product innovation success as product innovations' share in total sales. In particular, we asked respondents for the share of current sales obtained with innovative products that were introduced to the market within the last three years. This percentage is the variable Newproduct. Second, process innovation performance is considered by using a dummy Newprocess indicating whether the firm implemented at least one new process in the last three years (see e.g. Hall et al., 2009, who use the same concept of measurement). As can be seen in Table 1, about $60 \%$ of all firms in our sample innovated in the past three years (Inno). Firms on average achieved $16 \%$ of their sales with products that were introduced to the market within the past three years (Newproduct). Process innovations were implemented by $44 \%$ of all firms in the corresponding period (Newprocess).

\subsubsection{Explanatory variables}

Our main explanatory variables represent whether firms use different types of employees' ideas in the innovation process. We will verify whether these variables affect firm's innovation performance with respect to both new product and new process introduction. First, companies were asked to indicate whether they had used employees' suggestions in their innovation process in the past three years. The dummy variable Idea takes the value 1 if the firms responded "yes". In a second step, respondents indicated in which 'type' of individuals these ideas originated. More specifically, they were asked whether or not ideas from (a) the CEO, (b) administrative employees with management positions, (c) administrative employees without management positions, (d) production employees with management positions, (e) production employees without management positions, (f) $R \& D$ employees with management positions, (g) 
R\&D employees without management positions, (h) marketing/distribution employees with management positions and (i) marketing/distribution employees without management positions were used in the innovation process. We label these dummy variables (a) Idea_ceo, (b) Idea_adm_m, (c) Idea_adm_nm, (d) Idea_prod_m, (e) Idea_prod_nm, (f) Idea_r\&d_m, (g) Idea_r\&d_nm, (h) Idea_mkt_m and (i) Idea_mkt_nm respectively.

Based on these 9 dummy variables, we constructed the dummy Idea_m, which is equal to one if ideas of managerial employees different from the CEO were used. We also constructed the dummy variable Idea_nm, which is equal to one if non-managerial employees' ideas were used in the innovation process. As can be seen in Table 1, around $64 \%$ of all companies used CEOs', managers' or non-managerial employees' ideas in their innovation processes (Idea). Approximately $51 \%$ used their CEOs' ideas (Idea_ceo), $38 \%$ used ideas of other managers (Idea_m), while only $20 \%$ used non-managerial employees' ideas (Idea_nm). This confirms earlier findings that small firms rely mainly on their CEO to innovate (Burton, 20001) and that employees in small firms are seldom involved in valuable activities such as developing innovations (Klaas et al., 2010).

In addition to the main variables of interest, the survey also offers a rich set of relevant control variables. These more general controls are used as determinants of both the likelihood to innovate at all and our two innovation performance variables. Naturally, the firm's R\&D intensity will affect its propensity to innovate at all and also its innovation performance (see e.g. Pakes and Griliches, 1980). In line with work by Mueller (1966) and Faems et al. (2005), we operationalize the firms' R\&D intensity as the number of R\&D employees divided by total employment (Rdint). The R\&D personnel amount, on average, to $7.7 \%$ of the total workforce $\left(R \& D_{-} R d i n t\right)$. Furthermore, firm size measured by employment (Empl) allows controlling for potential scale and scope economies that larger firms may realize in their innovation process (see Cohen and Levin, 1989, for a survey). On average, companies in the sample employed 16 
people. Due to the skewness of the distribution, this variable enters the upcoming regression analysis as logarithm $(\operatorname{Ln}(E m p /))$. The firms' age $(A g e)$ is also used as control variable, as younger firms may be more innovative than older ones (e.g. Schneider and Veugelers, 2010). In particular, it may be the case that younger firms achieve a higher share of sales with new products simply because they have less established products than older firms. The average age of firms was 21.5 years old, but there was large variation from 1-208 years in business. Also this variable enters the regression analysis as logarithm $(\operatorname{Ln}($ Age $))$.

Further controls are a dummy indicating whether a firm is associated with a group of firms (Group) and the degree of product diversification (Div). Group members may be more innovative as they have better access to resources in terms of capital and knowledge that may spill-over from parent companies or affiliated subsidiaries more easily when compared to knowledge spill-overs to stand-alone companies (Pfaffermayr, 1999). For product innovations, group members may benefit from better access to markets through their affiliates' distribution system. The product diversification degree may, on the one hand, result in more innovation as companies may see more technological opportunities for innovation in their product markets and production processes (see e.g. Garcia-Vega, 2006). However, high diversification may also results in lower shares of sales with new products as innovations may only concern some submarkets of the firm's whole portfolio. Diversification (Div) is measured as 1 minus the share of sales obtained with the firm's most important product line. Thus, the index may take the value zero for a single product firm and approximate one for a highly diversified firm. About $27 \%$ of firms in our sample were associated with a company group (Group) and the diversification index was 0.271 at the mean (Div). Thus, firms in our sample achieved more than $70 \%$ of their sales with a single product, on average. Finally, evidence exists that sectors differ in the paces and rates of technological change (Pavitt, 1984). Therefore, we use four industry dummies to control for unobserved differences in innovation across sectors. Of the 305 small firms in our 
sample, 146 were active in manufacturing, 58 in construction, 23 in IT services, 35 in transportation and 43 in other business services. Descriptive statistics are presented in Table 1. Correlation statistics are presented in Table 2.

- INSERT TABLE 1 ABOUT HERE -

- INSERT TABLE 2 ABOUT HERE -

\subsection{Econometric model}

The questionnaire structure and its questions suggest using a Heckman selection model (Heckman, 1979). As firms were asked whether they used CEOs', managers' and nonmanagerial employees' ideas in their innovation process, it is desirable to differentiate between firms that were not intending to innovate at all and others ${ }^{I V}$. Therefore, a first equation explains the propensity to innovate

$$
\operatorname{Inno}_{i}^{*}=z_{i}^{\prime} \alpha+\varepsilon_{i},
$$

where Inno* represents the innovation propensity which is explained by the vector $z$ and a random error term $\varepsilon$ and where the coefficients $\alpha$ have to be estimated. Here the vector $z$ contains the general firm characteristics as described above. It is possible to observe the dummy variable

$$
\text { Inno }_{i}=\left\{\begin{array}{l}
1 \text { if } z_{i}^{\prime} \alpha+\varepsilon_{i}>0 \\
0 \text { otherwise }
\end{array}\right.
$$

\footnotetext{
IV The survey asks whether ideas were used in the innovation process. This implies that firms who respond affirmative must at least have planned to innovate in some form. Therefore, we want to control for the fact that a firm engages in innovation at all. This is achieved by estimating a Heckman selection model. If one would estimate the performance equation only on firms that actually innovate, one would possibly overestimate the average innovation performance as those companies with no innovation would not be included in the sample (data censoring problem). This problem can be tackled by the application of the sample selection model as the performance equation will contain a variable that controls for the correlation between the likelihood to innovate and the innovation performance.
} 
In a second step, the innovation performance equations are considered. First, we are interested in the performance with respect to new product sales and how this relates to employees' ideas.

$$
\text { Newproduct }_{i}^{*}=x_{i}^{\prime} \beta+e_{i} \text {, }
$$

where the vector $x$ are the covariates and $\beta$ its associated coefficients to be estimated and $e$ is the random error term. Here the vector $x$ contains the general firm characteristics as described above and the idea management variables. As Newproduct ${ }^{*}$ is not observed if Inno $=0$, the following selection rule is applied:

Newproduct $=$ Newproduct ${ }^{*}$ Inno $=1$ if $I n n 0^{*}>0$, and

Newproduct not observed, Inno $=0$ if $\operatorname{lnn} 0^{*} \leq 0$.

The standard Heckman selection model is completed by assuming that $\varepsilon$ and e follow a bivariate normal distribution. Then, the expected value of Newproduct can be written as (see e.g. Verbeek, 2000 , for technical details)

$$
E\left(\text { Newproduct }_{i} \mid x_{i}, \text { Inno }_{=}\right)=x_{i}^{\prime} \beta+\sigma_{\varepsilon e} \frac{\phi\left(z_{i}^{\prime} \hat{\alpha}\right)}{\Phi\left(z_{i}^{\prime} \hat{\alpha}\right)},
$$

where $\phi$ denotes the standard normal density function, $\Phi$ the standard normal cumulative distribution function and $\sigma$ is a coefficient to be estimated (the error terms' covariance). The second stage regression thus estimates product innovation performance conditional on being innovative at all.

For the dummy variable Newprocess the same model is used, with the exception that the second stage regression amounts to a probit model due to the outcome variable's binary nature (see van de Ven and van Praag, 1981). The second stage regression thus estimates process 
innovation performance conditional on being innovative at all. Both models are estimated by Full Information Maximum Likelihood (FIML) (see e.g. Verbeek, 2000, for more details) ${ }^{\mathrm{V}}$.

\section{Results}

Tables 3 and 4 present the regression results. In econometric theory, the coefficients in the Heckman selection model are identified because of the non-linearity of the Mills ratio entering the second stage regression even if the set of regressors is identical in both equations, i.e. $x=$ z. In practice, however, identification is more reliable when an exclusion restriction is used, that is, a variable that enters the selection equation, but not the second equation (see e.g. the discussion in Puhani, 2000). Ideally, the exclusion restriction would be based on theoretical reasoning. However, as there are no good priors as to what should drive the innovation dummy, but not the innovation performance (such as sales with new products or process innovation), an empirical strategy is applied to search for an exclusion restriction. It turns out that R\&D intensity (Rdint) is best specified as linear function in the outcome equation, but that it enters the selection equation in quadratic form. This implies that the models' coefficients are appropriately identified in the second equation.

\subsection{Effects on product innovation}

As mentioned above (and as seen in the lower part of Table 3), a firm's R\&D intensity (Rdint) has a highly significant impact on Inno and describes an inverse U-shape where the curve peaks at about $43 \%$. This corresponds to the $97^{\text {th }}$ percentile in the distribution of $R$ dint in the sample. Thus, one can conclude that Rdint has a positive impact on Inno with decreasing marginal effects as Rdint becomes larger. Furthermore, firm size as modeled by $L n(E m p l)$ also has a positive and significant impact on innovation. As expected, the diversification index Div

\footnotetext{
${ }^{v}$ The FIML procedure estimates the two equations jointly, instead of first estimating the propensity to innovate and then subsequently estimating the innovation performance equations separately.
} 
also affects the likelihood to innovate positively. The more diversified a firm's product portfolio, the more likely it will innovate. Furthermore, the industry dummies are jointly significant at the $1 \%$ level.

The second equation of Model A provides interesting results concerning the use of individuals' ideas in the innovation process. The general dummy, Idea, is highly significant and positive for new product sales indicating that small firms utilizing individual ideas from inside the firm are more successful in product innovation than other small firms. Hypothesis 1 is thus confirmed in the case of product innovation. In Model B, we distinguish between ideas from (a) the CEO, (b) other managers and (c) non-managerial employees. We find that using nonmanagerial employees' ideas (Idea_nm) has a significant positive effect on new product sales, which appears to confirm our Hypothesis 4 for product innovation. The contribution of CEOs' ideas (Idea_ceo) is significant at the $10 \%$ level, but using other managers' ideas (Idea_m) has no significant effect on new product sales. At first sight, hypothesis 2 is hence confirmed, whereas hypothesis 3 is not supported for product innovation. However, when looking in more detail into the managers' functional areas, we see that the picture is much more nuanced. While we do not find a joint effect of the use of managers' ideas, Model $\mathrm{C}$ shows that using R\&D managers' ideas (Idea_r\&d_m) actually has a positive effect on turnover from new products, which is significant at the $10 \%$ level.

\section{- INSERT TABLE 3 ABOUT HERE -}

The results concerning the control variables largely conform to expectations in the case of product innovation. In all three models, Rdint has a significant and positive effect, while $\operatorname{Ln}($ Age) has a significant negative effect on turnover from new products. Younger firms thus achieve higher sales with innovative products. Furthermore, the diversification index Div is basically insignificant except in model $\mathrm{C}$ where it is weakly negatively significant. These results show that firms having a diverse product portfolio may be more likely to innovate, but their 
product innovation performance is not affected significantly. Contrary to expectations, the effect of the Group dummy is negative. However, it is only weakly significant in model $C$ and otherwise insignificant. Thus we cannot make reliable conclusions about intra-firm knowledge spillovers. Also the industry dummies are not jointly significant.

Finally, note that the test on independence of the two equations in the regression models does not reject the null hypothesis of no dependence. Consequently, all models can be reestimated using only the subsample of innovating companies. All results from above were confirmed and therefore, these regressions are not presented in detail. In addition, we also estimated Tobit models, which are a restricted version of the selection models (see e.g. Verbeek, 2000, chapter 7). All significant effects as reported above were also found in the Tobit regressions. Therefore, we do not report these results in more detail.

\subsection{Effects on process innovation}

The lower part of Table 4 is of course highly consistent with our findings described above, given that we estimate the same equation, namely the propensity to innovate. The upper part of Table 4 describes the process innovation performance conditional on being innovative at all. In the second equation of Model D, we find that the dummy variable Idea has a positive significant effect on Newprocess indicating that firms utilizing ideas from their employees are more successful in process innovation than other firms. Hypothesis 1 is thus confirmed also for process innovation. When looking at the more detailed Model $E$ and Model $F$, we see - just like for product innovation performance - that we cannot draw general conclusions regarding the effect of the use of managers' and non-managerial employees' ideas. The detailed analyses by functional area in model $\mathrm{F}$ show that Idea_prod_m and Idea_prod_nm both have a positive significant effect on Newprocess. This implies that using ideas of production employees - with or without a management position - positively affects the firm's ability to introduce process innovations. In addition, we find a negative significant effect of Idea_mkt_m on Newprocess, 
which suggests that using marketing and distribution managers' ideas hinder a firm's process innovation activities. We do not find any significant effect of any other individual's ideas including those of the CEO/entrepreneur - on Newprocess. Hypothesis 2 is hence not supported in the case of process innovation.

For process innovation, the control variables perform poorly. Only the industry dummies explain differences in the average likelihood to introduce a process innovation in addition to the idea management variables. The low variation in the Newprocess variable within the sample of innovators may be the reason for this finding. Information on the extent of process innovation would be desirable, but is unfortunately not part of the current survey. Other surveys (e.g. The German and Flemish versions of the Community Innovation Survey) contain information on cost reductions or quality improvements due to process innovations. Such measurements should be included in future research on employee involvement's innovation performance effects.

Also here, the test for independence of the two equations in the regression models does not reject the null hypothesis of no dependence. The models were therefore re-estimated using only the subsample of innovating companies. The analyses confirmed the results above and are therefore not presented here in detail. We also estimated Tobit models for process innovation and the results were confirmed.

\section{- INSERT TABLE 4 ABOUT HERE -}

\section{Discussion and implications}

This article studies the extent to which small firms' innovative performance is affected by using CEOs', managers' and non-managerial employees' ideas in the innovation process. The analysis relies on a dataset of 305 small manufacturing and service firms, collected through a large-scale survey. The authors believe this work adds insights to existing literature in several 
ways. Firstly, while previous work studies the impact of employee involvement on the large firms' innovative performance, we are amongst the first to investigate this in small firms. We find that also in small firms, using ideas of managers but even of non-managerial employees significantly impacts a firm's innovative performance. More specifically, we show that for process innovation performance, small firms benefit greatly from suggestions by nonmanagerial production employees. Also for product innovation performance, we find a positive effect of using non-managerial employees' ideas. This suggests that the historical focus on the entrepreneur/CEO which was broadened more recently to the study of entrepreneurial teams does not yet fully capture small firms' innovative potential.

Secondly, existing empirical evidence regarding the importance of CEOs and top managers for innovation is inconclusive. While some authors find a positive relationship between small firms' managers' background and firm innovativeness, others do not. Some suggests that, although CEOs and managers affect innovative outcomes indirectly through their approach to hiring and employee management, they do not contribute their knowledge or skills directly to innovation. In this paper, we were able to test this hypothesis by explicitly measuring the use of CEOs', managers' and non-managerial employees' ideas in the innovation process. We find that, although CEOs generally do not provide relevant input for process innovation, their ideas are actually very relevant for product innovation. In addition, we show that R\&D managers' knowledge is highly relevant knowledge for product innovation, while production managers' suggestions contribute heavily to process innovation. At the same time, however, we show that ideas from R\&D managers do not contribute to process innovation, ideas from production managers do not contribute to product innovation and using ideas from managers in marketing/distribution or administration does not contribute to process nor product innovation. This implies that, depending on their functional expertise and the desired type of innovation, CEOs and managers actually do contribute their knowledge and skills directly to innovation. 
Wales et al. (2011) suggest that entrepreneurial orientation will manifest itself differently depending on the hierarchical levels and functional areas within an organization and on the firm's strategy or goals. We indeed show that non-managerial employees' contributions depend on their functional area of expertise as well as on the desired type of innovation. Using their ideas generally contributes to product innovation performance. For process innovation performance, only non-managerial employees from the production department - as opposed to non-managerial employees with a different functional background - appear to have valuable ideas. The results thus clearly imply that not all functional expertise is equally valuable for all types of innovation. With respect to managers' contributions, our finding that only R\&D managers and not marketing/distribution managers add to product innovation performance deserves some more attention. It is generally accepted that new products' success is largely determined by customer acceptance (Im and Workman, 2004) and that new product performance depends on the processing of market information, on understanding customer wants and needs (Ottum and Moore, 2003). Customer involvement in product development processes is recognized as an important source of information on customer needs (von Hippel, 1986; Franke et al., 2006; Olson and Bakke, 2001; Schoormans et al., 2003) and as a determinant for new product success (Lilien et al., 2002). Therefore, only employees that have direct contact with customers are expected to generate ideas that can lead to product development (von Hippel 1988). Although sales \& marketing employees are thought to have the best view on unsatisfied customer needs and competitors' new initiatives (Hyvärinen, 1990; Martin and Horne, 1995), our findings show that the main contribution to product innovation performance by managers comes from the R\&D department. This might possibly be explained by high customer involvement in the R\&D process of the firms in our sample. Unfortunately, we do not have any data on this. 
A first important managerial implication of our work is that small firms' CEOs should refrain from relying solely on their own actions and ideas in the innovation process. While some authors (e.g. Klaas et al., 2010) plead for an increased involvement of employees in small firms' innovation activities, we are the first to substantiate such call with empirical evidence. A second implication of our work is that both functional differences as well as differences between product and process innovation need to be taken into account when a firm intends to use ideas from employees in its innovation process. If a firm wants to excel in product innovation, it should focus mainly on using ideas from its CEO and R\&D managers. If it wants to excel in process innovation, attention should go to ideas from employees in the production department, including both production managers and non-managerial production employees. Whereas early models of innovation patterns at the industry level propose that product innovation dominates process innovation or vice versa (e.g. the product cycle model of Abernathy and Utterback, 1978; and the reverse product cycle model of Barras, 1986, 1990), more recent work on the firm level indicates that firm performance benefits from the cooccurrence and mutual strengthening of simultaneous product and process innovation (Pisano, 1997; Damanpour and Gopalakrishnan, 2001). This however should not instigate small firms to implement general company-wide knowledge management and gainsharing programs in the hope to raise both process and product innovation performance. Our research clearly indicates that separate - and perhaps simultaneous - initiatives to engage a select group of employees in either process or product innovation are far more efficient.

Of course, when interpreting the findings, one also needs to take into account the limitations of the study. One drawback is that we study the use of individuals' ideas without controlling for the quality of these ideas. It is well known that opportunity recognition capabilities differ between individuals and are dependent on human capital (Zarutskie, 2010; Dimov and Shepherd, 2005; Snell and Dean, 1992; Grant, 1996b; Tushman and Anderson, 1986; 
Ucbasaran et al., 2009), social capital (Bhagavatula et al., 2010; Davidsson and Honig, 2003), the use of different information sources (Ozgen and Bara, 2007) and other individual characteristics (e.g. Corbett, 2007; He, 2008). Our analyses do not take into account these individual characteristics.

A second limitation is that existing work points to a number of additional firm level characteristics that affect innovative activity, such as the availability of internal funds (Burt, 1992; Himmelberg and Petersen, 1994), the effectiveness of venture capital funding (Florida and Kenney, 1988; Kortum and Lerner, 1998), joint research with universities and other firms (Feller, 1990; Mansfield, 1991; Henderson et al., 1998; Mansfield and Lee, 1996), geographic location (Saxenian, 1990; Pouder and St John, 1996), documented innovation plans, market research and training and education (De Jong and Vermeulen, 2006). In addition, environmental dynamism is known to affect a firm's innovation strategy (Pérez-Luño et al., 2011). Including these firm and environmental characteristics as control variables would be opportune, but is not possible due to data limitations.

Thirdly, the data did not allow us to separately quantify process innovations' cost and efficiency effects. Also, as is often the case with survey data, our variables represent the respondents' perception, which may differ from the actual values.

And finally, the paper only looks at the effect of employee involvement on innovation performance. Although some (types of) individuals' ideas do not affect product or process innovation, they may lead to other desirable outcomes such as employee motivation, efficiency (e.g. doing non-innovative activities in a cheaper or better way). We full endorse the plea by Wales et al. (2011) to use a broader set of performance measures in this research field. There is definitely room for further SME studies on the effect of employee involvement - preferably by department or function - not only on innovation, but also on other firm outcomes. If possible, these studies should control for managers' and employees' individual characteristics, as well as 
for environmental characteristics. In addition, future work could try to provide in-depth understanding of the puzzling finding that suggestions of marketing/distribution managers hinder process innovation.

\section{References}

Allen, T. (1977). Managing the flow of technology: Technology transfer and the dissemination of technological information within the R\&D organization. MIT Press, Cambridge, MA.

Amabile, T. M. (1983). The social psychology of creativity: A componential conceptualization. Journal of Personality and Social Psychology, 45(2), 357-376.

Amit, R., \& Schoemaker, P. (1993). Strategic assets and organizational rent. Strategic Management Journal, 14, 33-46.

Argote, L., McEvily, B., \& Reagans, R. (2003). Managing knowledge in organizations: An integrative framework and review of emerging themes. Management Science, 49, 571-582.

Banbury, C. M., \& Mitchell, W. (1995). The effect of introduction important incremental innovations on market share and business survival. Strategic Management Journal, 19 (Special Issue), 42-55

Baird, L., \& Meshoulam, I. (1988). Managing two fits of strategic human resource management. Academy of Management Review, 13, 116-128.

Barker, V. L., III, \& Mueller, G. C. (2002). CEO characteristics and firm R\&D spending. Management Science, 48, 782-801.

Barney, J. (1995). Looking inside for competitive advantage. Academy of Management Executive, 17, 99-120.

Barney, J. (1991). Firm resources and sustained competitive advantage. Journal of Management, 17, 99-120. 
Barney, J. (1986). Organizational culture: Can it be a source of competitive advantage? Academy of Management Review, 11, 656-665.

Barney, J. B., \& Wright, P. M. (1998). On becoming a strategic partner: The role of human resources in gaining competitive advantage. Human Resource Management, 37, 31-46.

Bartlett, C. A., \& Ghoshal, S. (1993). Beyond the reform: Toward a managerial theory of the firm. Strategic Management Journal, 14, 23-46.

Bergmann Lichtenstein, B. M., \& Brush, C. G. (2001). How do 'resource bundles' develop and change in new ventures? A dynamic model and longitudinal exploration. Entrepreneurship, Theory and Practice, 25, 37-59.

Bhagavatula, S., Elfring, T., van Tilburg, A., \& van de Bunt, G. G. (2010). How social and human capital influence opportunity recognition and resource mobilization in India's handloom industry. Journal of Business Venturing, 25, 245-260.

Bledow, R., Frese, M., Anderson, N., Erez, M., \& Farr, J. L. (2009). A dialectic perspective on innovation: conflicting demands, multiple pathways, and ambidexterity. Industrial and Organizational Psychology: Perspectives on Science and Practice, 2(3), 305-337.

Boeker, W. (1997). Executive migration and strategic change: The effect of top manager movement on product market entry. Administrative Science Quarterly, 42, 231-236.

Borch, O. J., Huse, M., \& Senneseth, K. (1999). Resource configuration, competitive strategies and corporate entrepreneurship: An empirical examination of small firms. Entrepreneurship Theory and Practice, 24, 49-71.

Bowman, E.J. (1974). Epistemology, corporate strategy, and academe. Sloan Management Review 15, 35-50.

Brown, S. L., \& Eisenhardt, K. (1995). Product development: Past research, present findings, and future direction. Academy of Management Review, 20, 343-378. 
Brundin, E., Patzelt, H., \& Shepherd, D.A. (2008). Managers' emotional displays and employees' willingness to act entrepreneurially. Journal of Business Venturing, 3, 221-243.

Burgelman, R. (1991). Intraorganizational ecology of strategy making and organizational adaptation: theory and field research. Organization Science, 2, 239-262.

Brush, C. G., Greene, P. G., \& Hart, M. M (2001). From initial idea to unique advantage: The entrepreneurial challenge of constructing a resource base. Academy of Management Executive, 15, 64-78.

Burt, R. S. (1992). Structural holes: The social structure of competition. Cambridge, MA: Harvard University Press.

Burgelman, R.A. (1983). A process model of internal corporate venturing in the diversified major firm. Administrative Science Quarterly, 28, 223-)244.

Burton, D. M. (2001). The company they keep: Founders' models for organizing new firms. In C. B. Schoonhoven, \& Romanelli, E. (Eds.), The Entrepreneurship Dynamic: Origins of Entrepreneurship and the Evolution of Industries (pp. 13-39). Stanford, CA: Stanford University Press.

Cardon M., \& Stevens, C. (2004). Managing human resources in small organizations: What do we know? Human Resource Management Review, 14(3), 295-323.

Chaganti, R., \& Sambharya, R. B. (1987). Strategic orientation and upper management characteristics. Strategic Management Journal, 8, 393-401

Chaganti, R. S., Watts, A. D., Chaganti, R., \& Zimmerman-Treichel, M. (2008). Ethnicimmigrants in founding teams: Effects on prospector strategy and performance in new internet ventures. Journal of Business Venturing, 3, 113-139.

Ciavarella, M. A. (2003). The adoption of high-involvement practices and processes in emergent and developing firms: A descriptive and prescriptive approach. Human Resource Management, 42(4), 337-356. 
Cohen, W. M., \& Levin, R. C. (1989). Empirical studies of innovation and market structure. In R. Schmalensee, \& R. Willig (Ed.), Handbook of Industrial Organization (pp.1059-1107). Amsterdam: North-Holland.

Cohen, W. M., \& Levinthal, D. A. (1990). Absorptive capacity: A new perspective on learning and innovation. Administrative Science Quarterly, 35, 128-152.

Collins, C. J., \& Smith, K. G. (2006). Knowledge exchange and combination: The role of human resource practices in the performance of high-technology firms. Academy of Management Journal, 49(3), 544-560.

Conner, K. R., \& Prahalad, C. K. (1996). A resource-based theory of the firm: Knowledge versus opportunism. Organization Science, 7, 477-501.

Cook, M. F. (1999). Outsourcing human resource functions. New York: American Management Association

Cooper, R. G. (2001). Winning at new products: Accelerating the process from idea to launch. Cambridge, MA: Perseus Books.

Corbett, A. C. (2007). Learning asymmetries and the discovery of entrepreneurial opportunities. Journal of Business Venturing, 22, 97-118.

Damanpour, F. (1991). Organizational innovation: A meta-analysis of effects of determinants and moderators. Academy of Management Journal, 34, 555-590.

Damanpour, F. and Gopalakrishnan, S. (2001). The dynamics of the adoption of product and process innovations in organizations. Journal of Management Studies, 38(1), 45-65.

Daily, C. M., Certo, S. T., \& Dalton, D. R. (2000). A decade of corporate women: Some progress in the boardroom, none in the executive suite. Strategic Management Journal, 20, 93-99.

Datta, D. K., Guthrie, J. P., \& Wright, P. M. (2005). Human resource management and labor productivity: Does industry matter? Academy of Management Journal, 48, 135-145. 
Davidsson, P., \& Honig, B. (2003). The role of social and human capital among nascent entrepreneurs. Journal of Business Venturing, 18, 301-331.

De Jong, J. P. J., \& Vermeulen, P. A. M. (2006). Determinants of product innovation in small firms: a comparison across industries. International Small Business Journal, 24, 587-609.

De Winne, S., \& Sels, L. (2010). Interrelationships between human capital, HRM and innovation in Belgian start-ups aiming at an innovation strategy. The International Journal of Human Resource Management, 21(11), 1863-1883.

Dimov, D. P., \& Shepherd, D. A. (2005). Human capital theory and venture capital firms: Exploring "home runs" and "strike outs". Journal of Business Venturing, 20, 1-21.

Drazin, R., Glynn, M. A., and Kazanjian, R. K. (1999). Multilevel theorizing about creativity in organizations: A sensemaking perspective. Academy of Management Review, 21(2), 286307.

Drazin, R., \& Rao, H. (2002). Harnessing managerial knowledge to implement product-line extensions: How do mutual fund families allocate portfolio managers to old and new funds? Academy of Management Journal, 45, 609 - 619.

Eisenhardt, K. M., \& Martin, J. A. (2000). Dynamic capabilities: What are they? Strategic Management Journal, 21, 1105-1122.

Eurostat (2004). Innovation in Europe - Results for the EU, Iceland and Norway, Panorama of the European Union - Theme 9: Science and Technology. Luxembourg: Eurostat.

Faems, D., Van Looy, B., \& Debackere, K. (2005). Interorganizational collaboration and innovation: Toward a portfolio approach. Journal of Product Innovation Management, 22(3), 238-250.

Feller, I. (1990). Universities as engines of R\&D-based economic growth: They think they can. Research Policy, 19(4), 335-348. 
Fey, C. F., Björkman, I., and Pavlovskaya, A. (2000). The effect of human resource management practices on firm performance in Russia. International Journal of Human Resource Management, 11(1), 1-18.

Florida, R., \& Kenney, M. (1988). Venture capital in high technology entrepreneurship. Journal of Business Venturing, 3(4), 301-319.

Franke, N., von Hippel, E., \& Schreier, M. (2006). Finding commercially attractive user innovations: A test of lead-user theory. Journal of Product Innovation Management, 23(4), $301-315$.

Garcia-Vega, M. (2006). Does technological diversification promote innovation? An empirical analysis for European firms, Research Policy, 35, 230-246.

Garud, R., \& Nayyar, P. (1994). Transformative capacity: Continual restructuring by intertemporal technology transfer. Strategic Management Journal, 15, 365-385.

Grant, R. M. (1996a). Toward a knowledge-based theory of the firm. Strategic Management Journal, 17(S2), 109-122.

Grant, R. M. (1996b). Prospering in dynamically-competitive environments: Organizational capability as knowledge integration. Organization Science, 7, 375-387.

Grant, R. M. (1997). The knowledge-based view of the firm: Implications for management practice. Long Range Planning, 30(3), 450-454.

Grant, R. M. (1991). The resource-based theory of competitive advantage: Implications for strategy formulation. California Management Review, 33(3), 114-135.

Hall, B.H; Lotti, F. \& Mairesse, J. (2009). Innovation and productivity in SMEs: empirical evidence for Italy. Small Business Economics 33(1), 13-33.

Hambrick, D. C., \& Mason, P. A. (1984). Upper echelons: The organization as a reflection of its top managers. Academy of Management Review, 9(2), 193-206. 
Hansen, M. A. (1999). The search-transfer problem: The role of weak ties in sharing knowledge across organization subunits. Administrative Science Quarterly, 44, 82-111.

Hayek, F. A. (1945). The use of knowledge in society. American Economic Review, 35, 519532.

Hayton, J. C. (2003). Strategic human capital management in SMEs: An empirical study of entrepreneurial performance. Human Resource Management, 42(4), 375-391.

Heckman, J. J. (1979). Sample selection bias as a specification error Econometrica, 47(1), $153-161$.

He, L. (2008). Do founders matter? A study of executive compensation, governance structure and firm performance. Journal of Business Venturing, 23(3), 257-279.

Helfat, C. E., \& Raubitschek, R. S. (2000). Product sequencing: Co-evolution of knowledge capabilities and products. Strategic Management Journal, 21, 961-979.

Henderson, R., Jaffe, A. B., \& Trajtenberg, M. (1998). Universities as a source of commercial technology: A detailed analysis of university patenting 1965-1988. Review of Economics and Statistics, 80(1), 119-127.

Henderson, R. M., \& Clark, K. B. (1990). Architectural innovation: The reconfiguration of existing product technologies and the failure of established firms. Administrative Science Quarterly, 35, 9-30.

Henderson, R., \& Cockburn, I. (1994). Measuring core competence? Evidence from the pharmaceutical industry. Strategic Management Journal, 15, 63-84.

Himmelberg, C. P., \& Petersen, B. C. (1994). R\&D and internal finance: A panel study of small firms in high-tech industries. Review of Economics and Statistics, 76(1), 38-51.

Hitt, M. A., Bierman, L., Shimizu, K., \& Kochhar, R. (2001). Direct and moderating effects of human capital on strategy and performance in professional service firms: A resource-based perspective. Academy of Management Journal, 44(1), 13-28. 
Huselid, M. A. (1995). The impact of human resource management practices on turnover, productivity, and corporate financial performance. Academy of Management Journal, 38, $635-672$

Huselid, M. A. (2003). Editor's note: Special issue on small and medium-sized enterprises: A call for more research. Human Resource Management, 42(4), 297.

Hutchins, E. (1991). Organizing work by adjustment. Organization Science, 2, 14-39.

Hyvärinen, L. (1990). Innovativeness and its indicators in small- and medium-sized industrial enterprises. International Small Business Journal, 9(1), 64-79.

lansiti, M., \& Clark, K. B. (1994). Integration and dynamic capability: Evidence from product development in automobiles and mainframe computers. Industrial and Corporate Change, $3,557-605$

Im, S., \& Workman, J. P. Jr. (2004). Market orientation, creativity, and new product performance in high-technology firms. Journal of Marketing, 68(2), 114-132.

Kalleberg, A. L., \& Moody, J. W. (1994). Human resource management and organizational performance. American Behavioral Scientist, 37(7), 948-962.

Klaas, B. S., Klimchak, M., Semadeni, M., \& Holmes, J. J. (2010). The adoption of human capital services by small and medium enterprises: A diffusion of innovation perspective. Journal of Business Venturing, 25, 349-360.

Klepper, S., \& Simons, K. L. (2000). Dominance by birthright: Entry of prior radio producers and competitive ramifications in the U.S. television receiver industry. Strategic Management Journal, 21, 997-1016.

Kogut, B., \& Zander, U. (1992). Knowledge of the firm, combinative capabilities, and the replication of technology. Organization Science, 3, 383-397.

Kogut, B., \& Zander, U. (1993). Knowledge of the firm and the evolutionary theory of the multinational corporation. Journal of International Business Studies, 24, 625-645. 
Kogut, B., \& Zander, U. (1996). What firms do? Coordination, identity, and learning. Organization Science, 7, 502-518.

Kortum, S., \& Lerner, J. (1998). Does venture capital spur innovation? Working Paper No. 6846, National Bureau of Economic Research (NBER).

Kusunoki, K., Nonaka, I., \& Nagata, A. (1998). Organizational capabilities in product development of Japanese firms: A conceptual framework and empirical findings. Organization Science, 9(6), 699-718.

Lado, A. A., \& Wilson, M. C. (1994). Human resource systems and sustained competitive advantage: A competency based perspective. Academy of Management Review, 19, 699727.

Laursen, K., \& Salter, A. (2006). Open for Innovation: The role of openness in explaining innovative performance among UK manufacturing firms. Strategic Management Journal, Vol. 27(2), pp 131-150.

Liebeskind, J. P. (1996). Knowledge, strategy, and the theory of the firm. Strategic Management Journal, 17(S2), 93-107.

Lilien, G. L., Morrison, P. D., Searls, K., Sonnack, M., \& von Hippel, E. (2002). Performance assessment of the lead user idea-generation process for new product development. Management Science, 48(8), 1041-1059.

Lynskey, M. K. (2004). Determinants of innovative activity in Japanese technology-based startup firms. International Small Business Journal, 22, 159-196.

Madhavan, R., \& Grover, R. (1998). From embedded knowledge to embodied knowledge: New product development as knowledge management. Journal of Marketing, 62(4), 1-12.

Maes, J., Sels, L., \& Roodhooft, F. (2005). Modeling the link between management practices and financial performance: Evidence from small construction companies. Small Business Economics, 25, 17-34. 
Mansfield, E. (1991). Academic research and industrial innovation. Research Policy, 20(1), 112.

Mansfield, E., \& Lee, J.-Y. (1996). The modern university: Contributor to industrial innovation and recipient of industrial R\&D support. Research Policy, 25(7), 1047-1058.

March, J. G. (1991). Exploration and exploitation in organizational learning. Organization Science, 2, 71-87.

Martin, C. R., \& Horne, D. A. (1995). Level of success inputs for service innovations in the same firm. International Journal of Service Industry Management, 6(4), 40-56.

Michie, J., \& Sheehan-Quinn, M. (2001). Labour market flexibility, human resource management and corporate performance. British Journal of Management, 12, 287-306.

Michie, J., \& Sheehan, M. (1999). HRM Practices, R\&D expenditure and innovative investment: Evidence from the UK's 1990 Workplace Industrial Relations Survey. Industrial and Corporate Change, 8, 211-234.

Miller, D., \& Toulouse, J. M. (1986). Chief executive personality and corporate strategy and structure in small firms. Management Science, 32, 1389-1409.

Mintzberg, H., and Waters, J. A. (1985). Of strategies, deliberate and emergent. Strategic Management Journal, 6, 257-272.

Mohnen, P., \& Mairesse, J. (2002). Accounting for innovation and measuring innovativeness: An Illustrative framework and an application. American Economic Review, 92(2), 226-230.

Mueller, D. C. (1966). Patents, research and development, and the measurement of inventive activity. Journal of Industrial Economics, 15(1), 26-37.

Mumford, M. D., \& Gustafson, S. B. (1988). Creativity syndrome: integration, application, and innovation. Psychological Bulletin, 103(1), 27-43.

Nahapiet, J., \& Ghoshal, S. (1998). Social capital, intellectual capital, and the organizational advantage. Academy of Management Review, 23, 242-266. 
Nonaka, I. (1991). A dynamic theory of knowledge creation. Organization Science, 5, 14-37.

Nonaka, I., \& Takeuchi, H. (1995). The knowledge-creating company. New York: Oxford University Press.

OECD/Eurostat, 1997 (OECD). Proposed guidelines for collecting and interpreting technological innovation data - Oslo Manual. Paris: OECD.

Olson, E. L., \& Bakke, G. (2001). Implementing the lead user method in a high technology firm: A longitudinal study of intentions versus actions. Journal of Product Innovation Management, 18(6), 388-395.

Orlikowksi, W. J. (2002). Knowing in practice: enacting a collective capability in distributed organizing. Organization Science, 13(3), 249-273.

Ottum, B. D., \& Moore, W. L. (2003). The role of market information in new product success/failure. Journal of Product Innovation Management, 14(4), 258-273.

Ozgen, E., \& Baron, R. A. (2007). Social sources of information in opportunity recognition: Effects of mentors, industry networks, and professional forums. Journal of Business Venturing, 22, 174-192.

Pakes, A., \& Griliches, Z. (1980). Patents and R\&D at the firm level: A first report. Economics Letters, 5(4), 377-381.

Patzelt, H., zu Knyphausen-Aufse $\beta$, D., \& Fischer, H. T. (2009). Upper echelons and portfolio strategies of venture capital firms. Journal of Business Venturing, 4, 558-572.

Pavitt, K. (1984). Sectoral patterns of technological change: Towards a taxonomy and theory. Research Policy, 13(6), 343-373.

Pérez-Luño, A. Wiklund, J., \& Valle Cabrera, R. (2011). The dual nature of innovative activity: How entrepreneurial orientation influences innovation generation and adoption. Journal of Business Venturing. 26(5), 555-571. 
Pisano, G.P. (1997). The development factory: Unlocking the potential of process innovation. Harvard Business School Press, Boston.

Pouder, R., \& St John, C. (1996). Hot spots and blind spots: Geographic clusters of firms and innovation. Academy of Management Review, 21(4), 1192-1225.

Puhani, P. (2000). The Heckman correction for sample selection and its critique. Journal of Economic Surveys, 14(1), 53-68.

Quinn, J. B. (1992). Intelligent enterprise. New York: Free Press.

Rauch, A., Frese, M., \& Utsch, A. (2005). Effects of human capital and long-term human resources development and utilization on employment growth of small-scale businesses: A causal analysis. Entrepreneurship Theory and Practice, 29, 681-698.

Roper, S. Love, J. H., Dunlop, S., Ashcroft, B., Hofmann, H., \& Vogler-Ludwig, K. (1996). Product innovation and development in U.K., German and Irish manufacturing, NIERC/FAI, Queen's University of Belfast.

Saxenian, A. (1990). Regional networks and the resurgence of Silicon Valley. California Management Review, Fall, 89-113.

Schneider, C., \& Veugelers, R. (2010). On young highly innovative companies: Why they matter and how (not) to policy support them, Industrial and Corporate Change, 19(4), 9691007.

Schoormans, J. P. L., Ortt, R. J., \& de Bont, C. J. P. M. (2003). Enhancing concept test validity by using expert consumers. Journal of Product Innovation Management, 12(2), 153-162.

Sels, L., De Winne, S., Maes, J., Delmotte, J., Faems, D., \& Forrier, A. (2006). Unravelling the HRM-performance link: Value-creating and cost-increasing effects of small business HRM. Journal of Management Studies, 43(2), 319-342.

Snell, S. A., \& Dean, J. W. (1992). Integrated manufacturing and human resource management: A human capital perspective. Academy of Management Journal 35, 467-504. 
Shane, S. (2000). Prior knowledge and the discovery of entrepreneurial opportunities. Organization Science, 11(4), 448-469.

Shane, S., \& Venkatraman, S. (2000). The promise of entrepreneurship as a field of research. Academy of Management Journal, 25, 217-226.

Schuler, R. S., \& Jackson, S. E. (1987). Linking competitive strategies with human resource management practices. Academy of Management Executive, 1(3), 207-19.

Slevin, D. P., and Terjesen, S. A. (2011). Entrepreneurial orientation: Reviewing three papers and implications for further theoretical and methodological development. Entrepreneurship Theory and Practice, 35, 973-987.

Smith, K. G., Collins, C. J., \& Clark, K. D. (2005). Existing knowledge, knowledge creation capability, and the rate of new product introduction in high-technology firms. Academy of Management Journal, 48(2), 346-357.

Spender, J.-C. (1996). Making knowledge the basis of a dynamic theory of the firm. Strategic Management Journal, 17(S2), 45-62.

Stewart, T. A. (1997). Intellectual capital. New York: Doubleday-Currency.

Stopford, J. M., and Baden-Fuller, C. W. F. (1994). Creating corporate entrepreneurship. Strategic Management Journal, 15, 521-536.

Subramaniam, M., \& Youndt, M. A. (2005). The influence of intellectual capital on the types of innovative capabilities. Academy of Management Journal, 48(3), 450-463.

Szulanski, G. (1996). Exploring internal stickiness: Impediments to the transfer of best practice within the firm. Strategic Management Journal, 17, 27-43.

Teece, D. J., Pisano, G., \& Shuen, A. (1997). Dynamic capabilities and strategic management. Strategic Management Journal, 18, 509-533. 
Tsui, A. S., Pearce, J. L., Porter, L. W., \& Tripoli, A. M. (1997). Alternative approaches to the employee-organization relationship: does investment in employees pay off? Academy of Management Journal, 40, 1089-1121.

Tushman, M., \& Anderson, P. (1986). Technological discontinuities and organizational environments. Administrative Science Quarterly, 31, 439-465.

Ucbasaran, D., Westhead, P., \& Wright, M. (2009). The extent and nature of opportunity identification by experienced entrepreneurs. Journal of Business Venturing, 24, 99-115.

Unger, J., Rauch, A., Frese, M., \& Rosenbuch, N. (2011). Human capital and entrepreneurial success: A meta-analytical review. Journal of Business Venturing, 26(3), 341-358.

Van de Ven, W. P. M. M., \& Van Praag, B. M. S. (1981). The demand for deductibles in private health insurance: A probit model with sample selection, Journal of Econometrics, 17(2), 229-252.

Verbeek, M. (2000). A guide to modern econometrics. Chichester, England: John Wiley and Sons.

von Hippel, E. (1986). Lead users: A source of novel product concepts. Management Science, 32(7), 791-805.

von Hippel, E. (1988). The sources of innovation. New York and Oxford: Oxford University Press.

Wales, W., Monsen, E., and McKelvie, A. (2011). The organizational pervasiveness of entrepreneurial orientation. Entrepreneurship Theory and Practice, 35, 895-923.

Ward, T. B. (2004). Cognition, creativity, and entrepreneurship. Journal of Business Venturing, 19(2), 173-188.

Way, S. (2002). High performance work systems and intermediate indicators of firm performance within the US small business sector. Journal of Management, 28, 765-785. 
Wiig, K. M. (1997). Integrating intellectual capital and knowledge management. Long Range Planning, 30, 399-405.

Wright, P. M., \& McMahan, G. C. (1992). Theoretical perspectives for strategic human resource management. Journal of Management, 18, 295-320.

Wright, P. M., Dunford, B. B., \& Snell, S. A. (2001). Human resources and the resource based view of the firm. Journal of Management, 27, 701-721.

Zahra, S., \& Pearce, J. (1989). Boards of directors and corporate financial performance: A review and integrative model. Journal of Management, 15(2), 291-334.

Zander, U., \& Kogut, B. (1995). Knowledge and the speed of transfer and imitation of organizational capabilities: An empirical test. Organization Science, 6, 766-92.

Zarutskie, R. (2010). The role of top management team human capital in venture capital markets: Evidence from first-time funds. Journal of Business Venturing, 25, 155-172.

Zenger, T., \& Hesterly, W. S. (1997). The disaggregation of corporations: Selective intervention, high-powered incentives and molecular units. Organization Science, 8, 209222. 
Table 1: Descriptive statistics (305 observations)

\begin{tabular}{lrrrr}
\hline Variable & Mean & Std. Dev. & Min & Max \\
\hline Inno & 0.597 & 0.491 & 0 & 1 \\
Newproduct & 15.978 & 24.236 & 0 & 100 \\
Newprocess & 0.436 & 0.497 & 0 & 1 \\
Empl & 15.843 & 12.171 & 1 & 50 \\
Idea & 0.636 & 0.482 & 0 & 1 \\
Idea_m & 0.380 & 0.486 & 0 & 1 \\
Idea_nm & 0.197 & 0.398 & 0 & 1 \\
Idea_ceo & 0.508 & 0.501 & 0 & 1 \\
Idea_adm_m & 0.200 & 0.401 & 0 & 1 \\
Idea_adm_nm & 0.062 & 0.242 & 0 & 1 \\
Idea_prod_m & 0.203 & 0.403 & 0 & 1 \\
Idea_prod_nm & 0.131 & 0.338 & 0 & 1 \\
Idea_r\&d_m & 0.079 & 0.270 & 0 & 1 \\
Idea_r\&d_nm & 0.036 & 0.187 & 0 & 1 \\
Idea_mkt_m & 0.108 & 0.311 & 0 & 1 \\
Idea_mkt_nm & 0.043 & 0.202 & 0 & 1 \\
Rdint & 0.077 & 0.149 & 0 & 0.875 \\
Group & 0.148 & 0.355 & 0 & 1 \\
Div & 0.271 & 0.218 & 0 & 0.880 \\
Age & 21.506 & 24.628 & 1 & 208 \\
\hline
\end{tabular}

Note: Industry dummies omitted. 


\section{Table 2: Correlation statistics}

\begin{tabular}{|c|c|c|c|c|c|c|c|c|c|c|c|c|c|c|c|c|c|c|c|c|}
\hline & $\stackrel{\text { 읕 }}{\underline{\text { In }}}$ & $\begin{array}{l}\text { 임 } \\
\frac{0}{0} \\
\text { 임 } \\
\text { d }\end{array}$ & 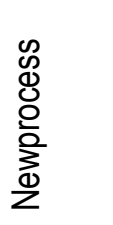 & 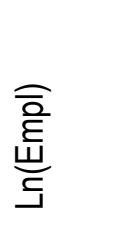 & 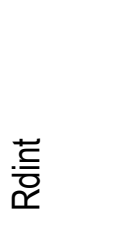 & $\begin{array}{l}\frac{}{3} \\
\frac{0}{0}\end{array}$ & : & 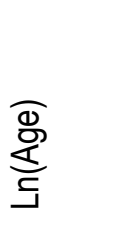 & $\begin{array}{l}\mathbb{\Phi} \\
\text { 으 }\end{array}$ & 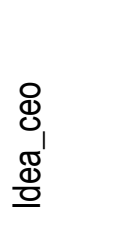 & 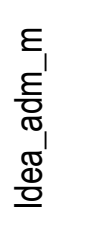 & $\begin{array}{l}E_{1} \\
\text { ס } \\
\text { 음 } \\
\mathbb{\Phi} \\
\text { 으 }\end{array}$ & 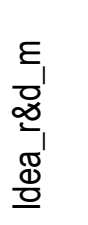 & 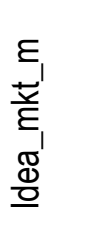 & 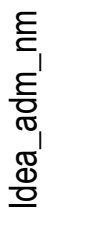 & 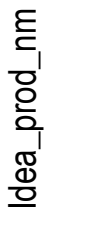 & 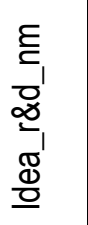 & $\begin{array}{l}\text { E } \\
\text { E } \\
\text { 피 } \\
\text { E } \\
\text { ㅁ } \\
\text { 으 }\end{array}$ & $\begin{array}{l}\text { E } \\
\text { 명 } \\
\text { 으 }\end{array}$ & 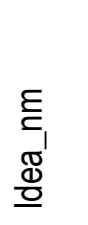 \\
\hline Inno & 1.00 & & & & & & & & & & & & & & & & & & & \\
\hline Newproduct & 0.54 & 1.00 & & & & & & & & & & & & & & & & & & \\
\hline Newprocess & 0.72 & 0.33 & 1.00 & & & & & & & & & & & & & & & & & \\
\hline Ln(Empl) & 0.19 & 0.00 & 0.14 & 1.00 & & & & & & & & & & & & & & & & \\
\hline Rdint & 0.30 & 0.48 & 0.19 & -0.10 & 1.00 & & & & & & & & & & & & & & & \\
\hline Group & 0.12 & 0.02 & 0.03 & 0.12 & 0.09 & 1.00 & & & & & & & & & & & & & & \\
\hline Div & 0.30 & 0.17 & 0.23 & 0.17 & 0.20 & 0.08 & 1.00 & & & & & & & & & & & & & \\
\hline Ln(Age) & 0.08 & -0.18 & 0.08 & 0.41 & -0.20 & -0.01 & 0.07 & 1.00 & & & & & & & & & & & & \\
\hline Idea & 0.42 & 0.35 & 0.36 & 0.19 & 0.27 & 0.10 & 0.16 & -0.02 & 1.00 & & & & & & & & & & & \\
\hline Idea_ceo & 0.38 & 0.30 & 0.31 & 0.18 & 0.17 & 0.08 & 0.17 & 0.00 & 0.77 & 1.00 & & & & & & & & & & \\
\hline Idea_adm_m & 0.21 & 0.17 & 0.14 & 0.18 & 0.04 & 0.05 & 0.10 & -0.03 & 0.38 & 0.34 & 1.00 & & & & & & & & & \\
\hline Idea_prod_m & 0.32 & 0.15 & 0.38 & 0.19 & 0.07 & -0.00 & 0.13 & 0.05 & 0.38 & 0.35 & 0.11 & 1.00 & & & & & & & & \\
\hline Idea_r\&d_m & 0.22 & 0.30 & 0.14 & 0.13 & 0.35 & 0.15 & 0.23 & 0.01 & 0.22 & 0.19 & 0.16 & 0.19 & 1.00 & & & & & & & \\
\hline Idea_mkt_m & 0.24 & 0.20 & 0.10 & 0.16 & 0.05 & 0.12 & 0.23 & 0.02 & 0.26 & 0.24 & 0.27 & 0.3 & 0.29 & 1.00 & & & & & & \\
\hline Idea_adm_nm & 0.10 & 0.18 & 0.05 & -0.01 & 0.15 & 0.08 & 0.08 & -0.11 & 0.2 & 0.17 & 0.31 & 0.00 & 0.08 & 0.17 & 1.00 & & & & & \\
\hline Idea_prod_nm & 0.26 & 0.22 & 0.27 & 0.05 & 0.10 & 0.14 & 0.10 & 0.01 & 0.29 & 0.21 & 0.15 & 0.24 & 0.07 & 0.24 & 0.26 & 1.00 & & & & \\
\hline Idea_r\&d_nm & 0.12 & 0.26 & 0.08 & -0.00 & 0.48 & 0.07 & 0.18 & -0.07 & 0.15 & 0.12 & -0.05 & 0.03 & 0.34 & -0.01 & 0.02 & 0.13 & 1.00 & & & \\
\hline Idea_mkt_nm & 0.17 & 0.20 & 0.11 & 0.10 & 0.19 & 0.19 & 0.07 & 0.01 & 0.16 & 0.11 & 0.06 & 0.14 & 0.12 & 0.19 & 0.21 & 0.21 & 0.31 & 1.00 & & \\
\hline Idea_m & 0.40 & 0.27 & 0.31 & 0.24 & 0.17 & 0.05 & 0.22 & 0.02 & 0.59 & 0.55 & 0.64 & 0.64 & 0.37 & 0.44 & 0.16 & 0.26 & 0.10 & 0.10 & 1.00 & \\
\hline Idea_nm & 0.29 & 0.35 & 0.25 & 0.03 & 0.29 & 0.21 & 0.13 & -0.07 & 0.37 & 0.26 & 0.17 & 0.16 & 0.13 & 0.17 & 0.52 & 0.79 & 0.39 & 0.43 & 0.27 & 1.00 \\
\hline
\end{tabular}


Table 2: Regression results for product innovation (305 observations)

\begin{tabular}{|c|c|c|c|}
\hline Model: & $A$ & $B$ & C \\
\hline & $\begin{array}{l}\text { Dependent variable: } \\
\text { Newproduct }\end{array}$ & $\begin{array}{c}\text { Dependent variable: } \\
\text { Newproduct }\end{array}$ & $\begin{array}{c}\text { Dependent variable: } \\
\text { Newproduct }\end{array}$ \\
\hline Idea & $11.738^{\star * *} \quad(4.184)$ & & \\
\hline $\begin{array}{l}\text { Idea_nm } \\
\text { Idea m }\end{array}$ & & $8.678^{* \star}$ & \\
\hline Idea_m & & -1.433 & \\
\hline Idea_ceo & & $7.779^{*}$ & $7.906^{* *}$ \\
\hline Idea_adm_m & & & (3.449) \\
\hline Idea_adm_nm & & & $(7.031)$ \\
\hline Idea_prod_m & & & $(4.096)$ \\
\hline Idea_prod_nm & & & $(4.009)$ \\
\hline Idea_r\&d_m & & & $10.109^{*}$ \\
\hline Idea_r\&d_nm & & & $(10.080)$ \\
\hline Idea_mkt_m & & & $(4.251)$ \\
\hline Idea_mkt_nm & & & $(9.622)$ \\
\hline Ln(Empl) & -1.495 & $(2.271)$ & $(2.238)$ \\
\hline Rdint & $30.612^{* *} \quad(14.244)$ & $32.956^{* *}$ & $29.238^{* \star} \quad(13.984)$ \\
\hline Group & $(4.332)$ & $(4.534)$ & $-8.250^{*}$ \\
\hline Div & -10.670 & $(8.257)$ & $-14.744^{*}$ \\
\hline Ln(Age) & $-6.070^{\star * *}$ & $-6.087^{\star \star *}$ & $\begin{array}{ll}-6.548^{* * *} & (1.906)\end{array}$ \\
\hline Intercept & $36.506^{\star * *} \quad(9.112)$ & $36.742^{* * *} \quad(8.077)$ & $42.124^{* \star *} \quad(8.792)$ \\
\hline \multirow[t]{2}{*}{$\begin{array}{l}\text { Joint significance of } \\
4 \text { industry dummies }\left[\chi^{2}(4)\right]\end{array}$} & 6.10 & 5.44 & 3.87 \\
\hline & $\begin{array}{l}\text { Dependent variable: } \\
\text { Inno }\end{array}$ & $\begin{array}{l}\text { Dependent variable: } \\
\text { Inno }\end{array}$ & $\begin{array}{l}\text { Dependent variable: } \\
\text { Inno }\end{array}$ \\
\hline Ln(Empl) & $0.260^{* *} \quad(0.108)$ & $0.261^{* *} \quad(0.108)$ & $0.265^{* *} \quad(0.108)$ \\
\hline Rdint & $8.489^{* * *}(1.498)$ & $8.453^{* * *}(1.503)$ & $8.448^{\star * \star}(1.502)$ \\
\hline $\operatorname{Rdint}^{2}$ & $-9.723^{* * *}(2.062)$ & $-9.648^{* * *}(2.074)$ & $-9.627^{* \star *} \quad(2.080)$ \\
\hline Group & $0.209 \quad(0.274)$ & $0.206 \quad(0.274)$ & $0.213 \quad(0.276)$ \\
\hline Div & $0.938^{* *} \quad(0.406)$ & $0.936^{* *} \quad(0.406)$ & $0.945^{* *} \quad(0.407)$ \\
\hline Ln(Age) & $0.092 \quad(0.079)$ & $0.093 \quad(0.079)$ & $0.093 \quad(0.079)$ \\
\hline Intercept & $-0.948^{\star * *}(0.324)$ & $-0.951^{* * *}(0.324)$ & $-0.964^{* * *}(0.325)$ \\
\hline $\begin{array}{l}\text { Joint significance of } \\
4 \text { industry dummies }\left[\chi^{2}(4)\right]\end{array}$ & $22.18^{* * *}$ & $22.02^{* * *}$ & $22.04^{* * *}$ \\
\hline $\begin{array}{l}\mathrm{LR} \text { test on independent } \\
\text { equations }\left(\sigma_{\varepsilon \varepsilon}=0\right):\left[\chi^{2}(1)\right]\end{array}$ & 2.14 & 1.90 & 2.63 \\
\hline Log Likelihood & -971.20 & -969.52 & -967.30 \\
\hline
\end{tabular}

Note: Standard errors in parentheses. ${ }^{* * *}\left({ }^{* *},{ }^{*}\right)$ indicate a significance level of $1 \%(5 \%, 10 \%)$. 
Table 4: Regression results for process innovation (305 observations)

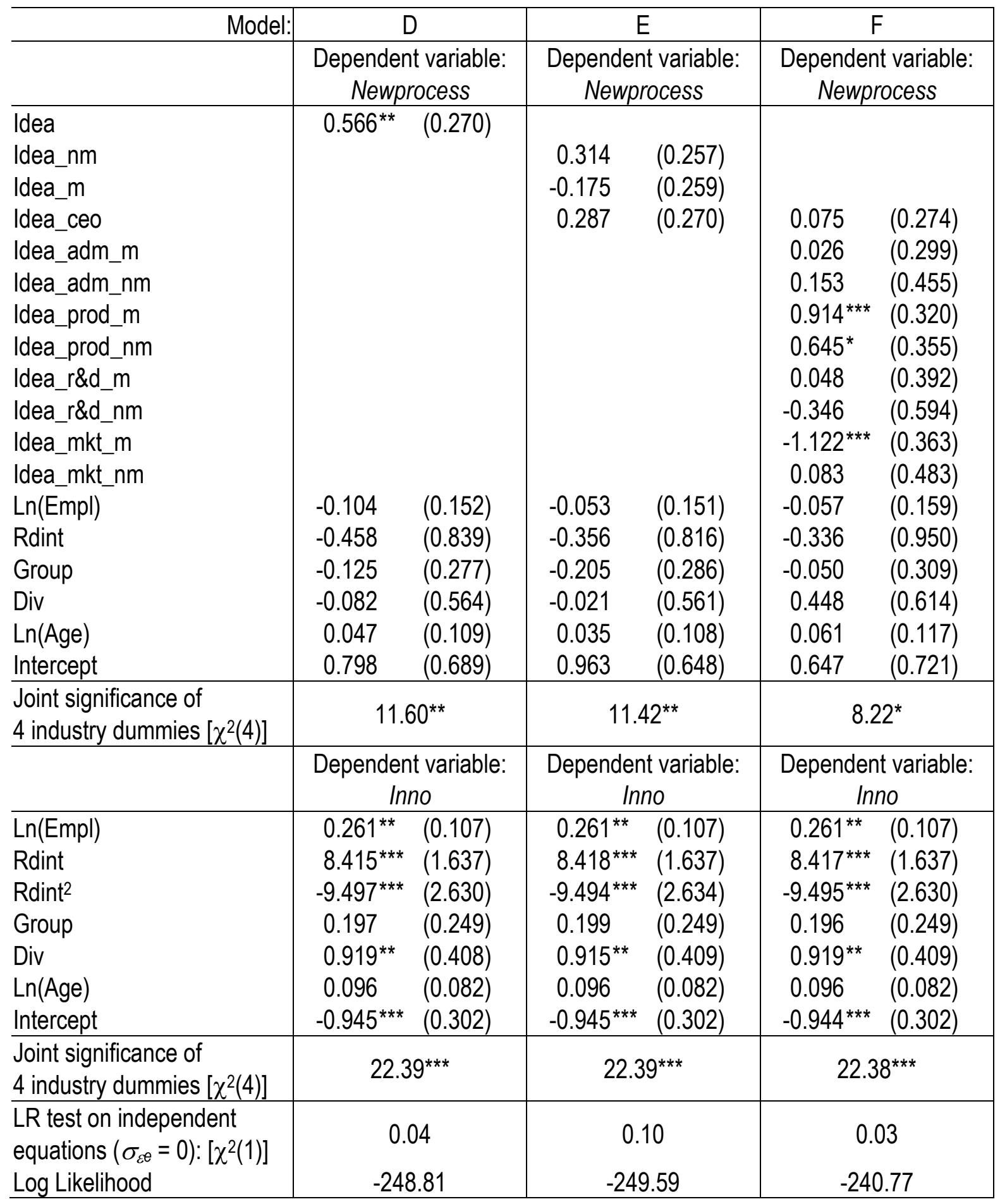

Note: Standard errors in parentheses. ${ }^{* * *}\left({ }^{* *},{ }^{*}\right)$ indicate a significance level of $1 \%(5 \%, 10 \%)$. 